\title{
赤外拡散反射法による塩製品の硫酸イオン含有量の簡易 測定法
}

\author{
吉川 直人 ${ }^{\circledR *}$, 佐藤 寿邦 ${ }^{* *}$, 大矢 晴彦 ${ }^{* *}$
}

\section{Simple method for the determination of sulfate ion in salt products by IR diffuse reflectometry}

\author{
Naohito YoshikaWA*, Hisakuni Sato and Haruhiko OHYA**
}

* Sea Water Science Research Laboratory, The Salt Industry Center of Japan, 4-13- 20, Sakawa, Odawara-shi, Kanagawa 256-0816

** Department of Material Science and Chemical Engineering, Faculty of Engineering, Yokohama National University, 79-5, Tokiwadai, Hodogaya-ku, Yokohama-shi, Kanagawa 240-0067

(Received 7 April 1998, Accepted 26 May 1998)

\begin{abstract}
Since the sulfate ion is a main impurity contained in highly pure salt products manufactured through a dissolution purification process, controlling the content of the sulfate ion in the salt products is important concerning the aspect of salt production. The authors studied a simple method for determining the sulfate ion content by IR diffuse reflectometry and, as a result, developed a simple determining method capable of determining the sulfate-ion content of highly pure salts without destruction and with a smaller determining error of around $\pm 10 \mathrm{mgkg}^{-1}$ and a higher repetition accuracy (RSD), of $4.6 \%$. In this method, the peak strength of SO degenerate stretching vibrations specific to the sulfate ion, which was determined by IR diffuse reflectometry, is corrected using the variation of the K-M value of $1900-2090 \mathrm{~cm}^{-1}$ caused by effects of the filling condition, particle size and particle-size distribution of the test sample on the degree of light scattering; also, the effects of the ambient temperatures and humidity are corrected using the absolute humidity. This method has sufficient accuracy for a simple determination, which enables a sulfate ion determination within a short time of approximately one minute, and is therefore, considered, to be thoroughly adaptable to product and process control.
\end{abstract}

Keywords : IR diffuse reflectometry; sulfate ion; rapid and simple determination; SO degenerate stretching; salt-manufacturing process.

$$
1 \text { 緒 言 }
$$

* (財)塧事業センター海水総合研究所：256-0816 神奈 川県小田原市酒匂 4-13-20

** 横浜国立大学工学部物質工学科:240-0067 神奈川県横 浜市保土ヶ谷区常盤台 79-5
日本の製塩工場は，イオン交換膜電気透析法による方 法 (イオン製塩法)，天日塩を原料として再製する方法 （溶解再製製塩法）により製塩を行っている.このうち, 溶解再製製塩法は，天日塩を水に溶解し，不純物である 
カルシウム，マグネシウムイオンを精製操作により除去 した精製 “かん水”を用いて高純度塩の製造を行ってお り, 最終的な不純物は硫酸イオンが主体となるため", 製品の硫酸イオン含有量の管理が重要である.

従来より, 製品の硫酸イオン含有量の管理は, イオン クロマトグラフ法 (IC) により行っている2). しかし, 溶解, 希釈等の試料の前処理が必要であり, 分析時間も 12 分程度を要するため, 簡易で迅速な測定法の開発が 求められている. そこで, 製品管理, 工程管理に対応で きる簡易測定法として，簡便，迅速で，試料を非破壊測 定できる赤外拡散反射法に着目した。

赤外拡散反射法を用いた場合，試料の内容成分に特有 の吸収があれば，その成分を定量できる可能性が高い3). 硫酸イオンには $1104 \mathrm{~cm}^{-1}$ に特有の SO 縮重伸縮振動吸 收 ${ }^{4}$ が存在するため, 硫酸イオン含有量の定量の可能性 は高いと考えられる．更に塩の主成分は吸収係数が小さ く，拡散反射測定の希瀵梸として用いられるハロゲン化 アルカリ ゙)であることから，適用の可能性は高い，又， 赤外拡散反射法は，試料の前処理を全く必要とせず，測 定時間も 1 分程度で, IC 法に比べ非常に短時間である. 従って，本法が適用できれば，迅速な製品管理や工程管 理に有用な方法となる。

著者らは，赤外拡散反射法により測定した硫酸イオン のピーク強度を，試料の充てん状態，粒径及び粒径分布 による光散乱度の影響に起因する 1900〜 $2090 \mathrm{~cm}^{-1}$ の Kubelka-Munk（K-M）值の変化量により補正し，又環 境温湿度の影響を絶対湿度で補正することにより，測定 誤差 $\pm 10 \mathrm{mg} \mathrm{kg}^{-1}$, 繰り返し精度 $4.6 \%$ で, 高純度塩の 硫酸イオン含有量を非破壊で簡易測定できる方法を開発 したので報告する。

\section{2 実験}

\section{$2 \cdot 1$ 実験装置及び方法}

Perkin Elmer 製 FT-IR Model 1650，Spectra Tech 製 拡散反射装置 Model 0001-367を用いて, 塩化ナトリウ 厶試薬（和光純薬製，純度 $99.98 \%$ ）を比較標準物質と して，拡散反射スペクトルを測定した。測定したスペク トルは, FT-IRに付属のデータ処理プログラムにより $\mathrm{K}-\mathrm{M}$ 変換した。スペクトルの測定条件は, 測定波数 $4000 \sim 800 \mathrm{~cm}^{-1}$, 分解能 $4 \mathrm{~cm}^{-1}$, スキャン回数 16 回で, 1 点の試料につき 3 回ずつ繰り返し測定した。試料は次 項に示す処理をした後, 試料ホルダー (容積 $0.40 \mathrm{~cm}^{3}$ ) に充てんし，スパチュラで表面を平滑にして測定した。 試料の充てん密度の影響について検討するため, スペク トル測定後に試料をひょう量した。

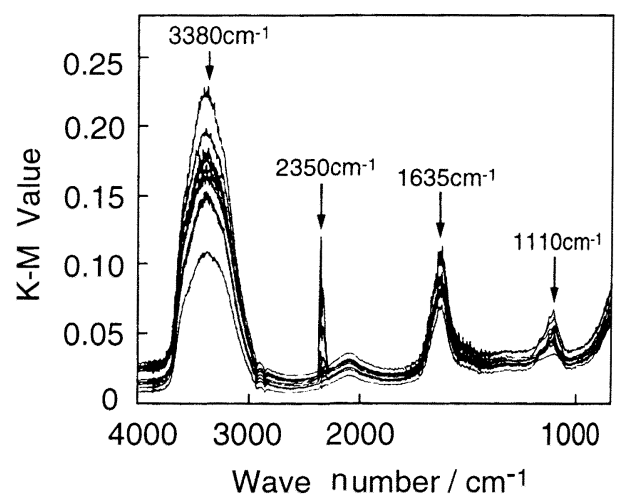

Fig. 1 DRS-IR spectra of the high purity salt products

\section{$2 \cdot 2$ 試 料}

溶解再製製塩法で製造された製品 22 点を製品試料と して，ふるい分け法により粒径分布を測定した。

試料粒径の影響について検討するため，製品試料を用 いてふるい分け法により 212～250，300～355，425〜 $500 \mu \mathrm{m}$ の 3 種類の分級試料を調製した.

製塩工場の包装工程の温湿度の影響について檢討する ため，製品試料を環境温湿度が $20{ }^{\circ} \mathrm{C} 40 \% ， 40{ }^{\circ} \mathrm{C} 40 \%$, $40{ }^{\circ} \mathrm{C} 70 \%$ の環境下に 3 日間静置することにより 3 種類 の環境試料を調製した。

\section{$2 \cdot 3$ 試料の分析}

試料の硫酸イオン含有量の分析は公定法 ${ }^{2} に$ 従い, IC 法により行った。

\section{$2 \cdot 4$ ピークの同定 ${ }^{4) 6}$}

Fig. 1 に赤外拡散反射スペクトルの一例を示す. 1110 $\mathrm{cm}^{-1}$ のピークは $\mathrm{SO}$ 縮重伸縮振動のピークであり, 磕 酸イオンの吸収を示す。この硫酸イオンのピークには, 他のピークとの重なりは見られなかった。 $1635 \mathrm{~cm}^{-1}$ のピークは $\mathrm{HOH}$ 変角振動のピークであり, $3380 \mathrm{~cm}^{-1}$ のピークは $\mathrm{OH}$ 伸縮振動と $\mathrm{HOH}$ 変角振動倍音が重な ったピークであり，共に付着水等の水の吸収を示す、又， $2350 \mathrm{~cm}^{-1}$ には二酸化炭素の吸収が見られる. 水のピー ク強度は，同一の環境条件下に打いても大きな変化蚖 られた。 又, 硫酸イオンのピーク強度も大きく変化し た。

$2 \cdot 5$ ピーク強度の算出

硫酸イオンのピーク強度 $I\left(\mathrm{SO}_{4}\right)$ は, $1240 \mathrm{~cm}^{-1}$ の $\mathrm{K}$ - 


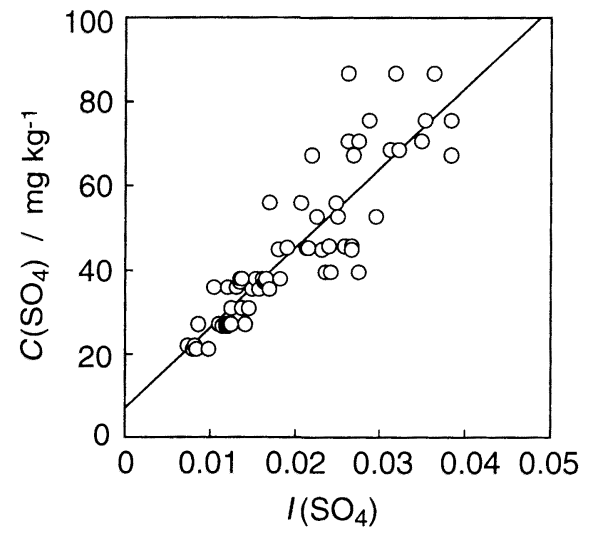

Fig. 2 Relation between the $I\left(\mathrm{SO}_{4}\right)$ value and the sulfate ion content by IC

$\mathrm{M}$ 值をべースとしたときの $1110 \mathrm{~cm}^{-1}$ の $\mathrm{K}-\mathrm{M}$ 值で算出 した，又，水の吸収を示す $\mathrm{HOH}$ 変角振動のピーク強度 $I(\mathrm{HOH})$ は $1780 \mathrm{~cm}^{-1}$ をべースとしたときの $1635 \mathrm{~cm}^{-1}$ の $\mathrm{K}-\mathrm{M}$ 值で, $\mathrm{OH}$ 伸縮振動と $\mathrm{HOH}$ 変角振動倍音のピ 一ク強度 $I(\mathrm{OH})$ は, $3770 \mathrm{~cm}^{-1}$ の K-M 值をべースとし たときの $3380 \mathrm{~cm}^{-1}$ の $\mathrm{K}-\mathrm{M}$ 值で算出した. 更に, 光散 乱度に関係すると考えられる 1900 $2090 \mathrm{~cm}^{-1}$ の K-M 值の変化量 $I(\mathrm{~S} 1)$ を算出した.

\section{3 結果及び考察}

\section{$3 \cdot 1$ 基礎的検討}

Fig. 2 に環境温湿度 $20{ }^{\circ} \mathrm{C}, 40 \%$ の製品試料の硫酸イ オン含有量の IC 法による分析值 $C\left(\mathrm{SO}_{4}\right)$ と $I\left(\mathrm{SO}_{4}\right)$ との 関係を示す。これらの間には直線関係が見られ, 高純度 塩の硫酸イオン含有量は 20〜 $100 \mathrm{mg} \mathrm{kg}^{-1}$ であることか ら, 硫酸イオン含有量の簡易測定に赤外拡散反射法を適 用できる可能性が示唆された. しかし, 分散の推定值は 72.71 であり, 直線の適合性は必ずしも良好ではなかっ た.

製品試料 22 点の粒径分布を正規分布で近似した場 合, 平均粒径の平均値は $330 \mu \mathrm{m}$, 標準偏差の平均值は $105 \mu \mathrm{m}$ であった，又，平均粒径の相対標準偏差（RSD） は $3.2 \%$ ，標準編差の RSD は $6.4 \%$ であった。このよう に，製品試料は平均粒径とともに微粒，大粒の存在によ り粒径分布も変化する. 又, 試料の充てん密度も変化す る.このため, $I\left(\mathrm{SO}_{4}\right)$ は, 粒径, 粒径分布及び試料の 充てん密度による光散乱度の影響》を受けることが考え られ，これらの影響を補正することが必要である。

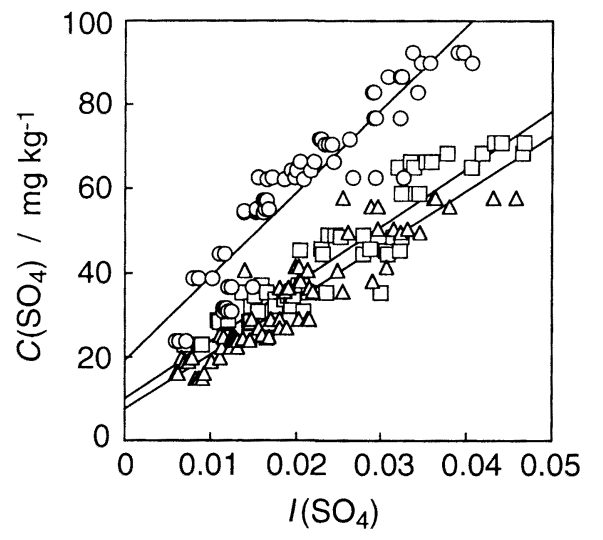

Fig. 3 Relation between the $I\left(\mathrm{SO}_{4}\right)$ value and the sulfate ion content by IC

$\bigcirc: 212 \sim 250 ; \square: 300 \sim 355 ; \triangle: 425 \sim 500 \mu \mathrm{m}$

\section{$3 \cdot 2$ 充てん密度の影響}

拡散反射測定に打いて, 光散乱度は試料の充てん密度 により変化することが考えられる。しかし, 製品試料 は, 平均粒径が $310 \sim 350 \mu \mathrm{m}$ と大きく, 乳鉢等で粉砕 した微粒子を試料ホルダーに充てんする場合のように試 料を圧密充てんできない。このため, 拡散反射スペクト ルの測定時に 22 点の製品試料について 3 回ずつ測定し た充てん密度の RSD は $2.0 \%$ であり, 製品試料の粒径 及び充てん操作による充てん密度のばらつきは小さかっ た. 又, 充てん密度を光散乱度に関係する 1 因子とし てとらえ, スペクトルの強度との関係を種々検討した が, 関連性は見られなかった。これは, 充てん密度を同 一にした場合においても充てん状態は均一にならず，光 散乱度は充てん密度ではなく, むしろ充てん状態により 影響を受けるためであると考えられる。

\section{$3 \cdot 3$ 粒径の影響と補正}

Fig. 3 に 3 種類の分級試料の $C\left(\mathrm{SO}_{4}\right)$ と $I\left(\mathrm{SO}_{4}\right)$ との 関係を示す。これらの間には, 分級試料ごとに值線関係 が見られた. 又, 分散の推定值は, 25.83〜 54.77 と製品 試料と比較して, 直線の適合性は良好であった. 分級試 料では粒径がほぼ一定であり, 試料の充てん状態もあま り変化せず, 光散乱度の変化が小さかったためと考えら れる. しかし, 粒径が異なると光散乱度は変化するた め, 異なる粒径の分級試料は, 同一の直線で表すことが できなかった。

Fig. 4 に $I\left(\mathrm{SO}_{4}\right)$ を光散乱度に関係すると考えられる 波数 $1900 \sim 2090 \mathrm{~cm}^{-1}$ の $\mathrm{K}-\mathrm{M}$ 值の変化量 $I(\mathrm{~S} 1)$ で補正 


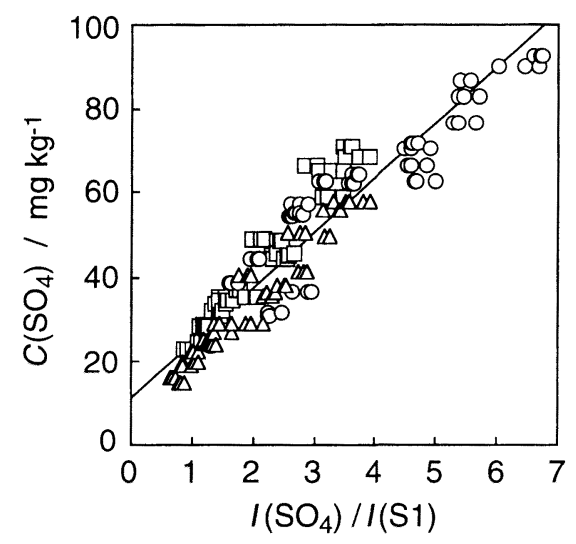

Fig. 4 Relation between the $I\left(\mathrm{SO}_{4}\right) / I(\mathrm{~S} 1)$ value and sulfate ion content by IC

$\bigcirc: 212 \sim 250 ; \square: 300 \sim 355 ; \triangle: 425 \sim 500 \mu \mathrm{m}$

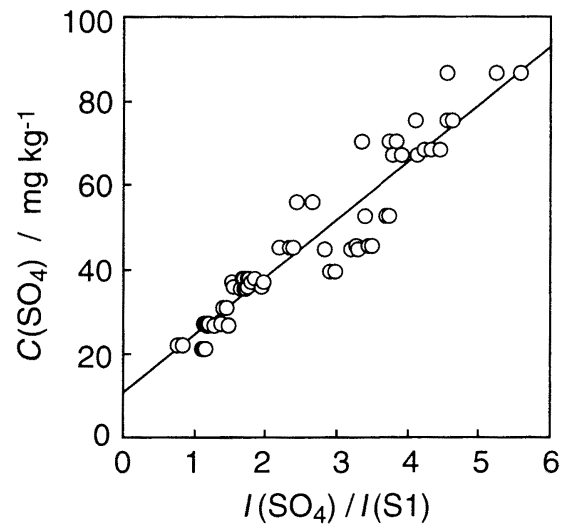

Fig. 5 Relation between the $I\left(\mathrm{SO}_{4}\right) / I(\mathrm{SI})$ value and sulfate ion content by IC

した值 $I\left(\mathrm{SO}_{4}\right) / I(\mathrm{~S} 1)$ と $C\left(\mathrm{SO}_{4}\right)$ との関係を示す。これ らの間には, 試料粒径によらず一定の直線関係が見られ た. 又, 分散の推定值は 40.98 であり, 直線の適合性は 良好であった。この結果, 粒径の影響は光散乱度に関係 すると考えられる $I(\mathrm{~S} 1)$ により補正することが可能とな った.

\section{$3 \cdot 4$ 粒径分布の影響と補正}

Fig. 5 に Fig. 2 と同一の製品試料で測定した $C\left(\mathrm{SO}_{4}\right)$ と $I\left(\mathrm{SO}_{4}\right) / I(\mathrm{~S} 1)$ との関係を示す。これらの間には直線 関係が見られた。 又, 分散の推定值は 39.27 であり, Fig. 2 の $C\left(\mathrm{SO}_{4}\right)$ と $I\left(\mathrm{SO}_{4}\right)$ の場合の 72.71 と比較して,

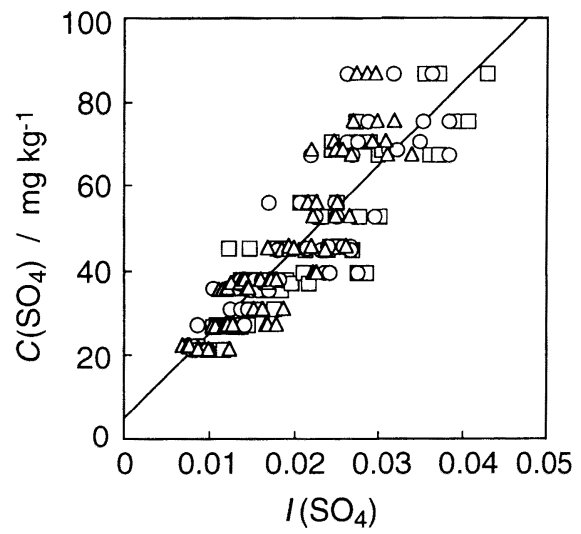

Fig. 6 Relation between the $I\left(\mathrm{SO}_{4}\right)$ value and sulfate ion content by IC

$\bigcirc: 20^{\circ} \mathrm{C}, 40 \% ; \square: 40{ }^{\circ} \mathrm{C}, 40 \% ; \triangle: 40^{\circ} \mathrm{C}, 70 \%$

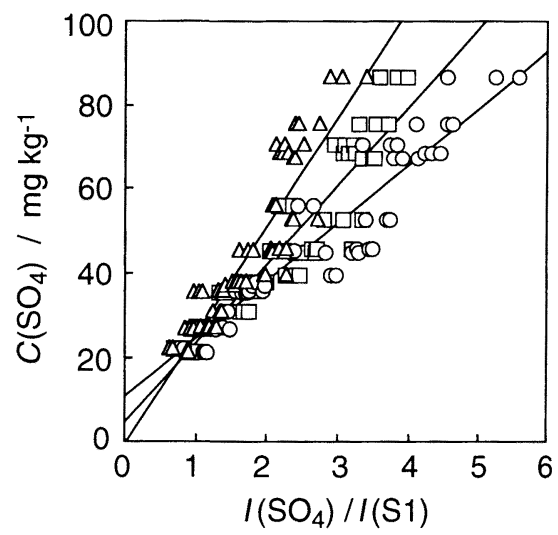

Fig. 7 Relation between the $I\left(\mathrm{SO}_{4}\right) / I(\mathrm{~S} 1)$ value and sulfate ion content by IC

$\bigcirc: 20^{\circ} \mathrm{C}, 40 \% ; \square: 40^{\circ} \mathrm{C}, 40 \% ; \triangle: 40^{\circ} \mathrm{C}, 70 \%$

適合性は大幅に向上した。この結果，粒径分布，充てん 状態による影響も $I(\mathrm{~S} 1)$ で補正できることが分かった $3 \cdot 3$ 項を含めた結果から, 粒径, 粒径分布及び充てん状 態による光散乱度の影響は， $I(\mathrm{~S} 1)$ で補正することが可 能となった。

\section{$3 \cdot 5$ 環境温湿度の影響と補正}

Fig. 6 に環境温湿度を変化させた環境試料の $C\left(\mathrm{SO}_{4}\right)$ と $I\left(\mathrm{SO}_{4}\right)$ との関係を示す. 硫酸イオンのピーク強度は, 環境温湿度の影響を受けずに，同一の直線で表すことが できた。しかし, 光散乱度の影響を受けるため, 分散の 


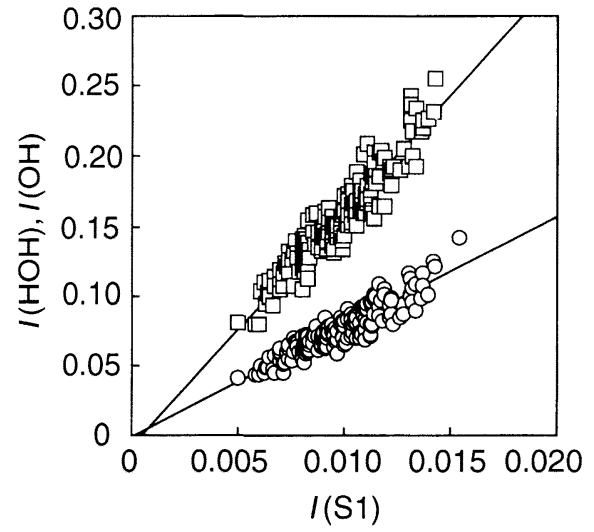

Fig. 8 Relation between the $I(\mathrm{HOH})$ value, the $I(\mathrm{OH})$ value and the $I(\mathrm{~S} 1)$ value

$\bigcirc$ : the $I(\mathrm{HOH})$ value; $\square$ : the $I(\mathrm{OH})$ value

推定値は 74.78 と直線の適合性は良好ではなかった.

Fig. 7 に $C\left(\mathrm{SO}_{4}\right)$ と $I\left(\mathrm{SO}_{4}\right) / I(\mathrm{~S} 1)$ との関係を示す. これらは，同一の環境条件においては，各々良好な直線 関係（分散の推定值 39.27～59.15）にあった。しかし， 環境温湿度が異なる場合には，同一の直線で表すことが できなかった.

Fig. 8 に $I(\mathrm{~S} 1)$ に対する, $\mathrm{HOH}$ 変角振動吸収を示す ピーク強度 $I(\mathrm{HOH})$ と, $\mathrm{OH}$ 伸縮振動と $\mathrm{HOH}$ 変角振 動倍音の吸収を示すピーク強度 $I(\mathrm{OH})$ との関係を示す. これらの間には，良好な直線関係が見られた。水のピー ク強度は, 試料水分と光散乱度の両方の影響を受けると

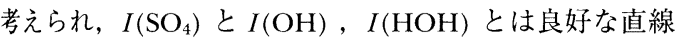
関係にあったことから，光散乱度の補正に用いた $I(\mathrm{~S} 1)$ は, 光散乱度とともに，試料水分の影響も受けると考え られる，そこで，光散乱度の補正について，試料水分の 影響を受けない波数域の検討を重ねたが，好適な波数域 は見いだせなかった。

\section{$3 \cdot 6$ 絶対湿度による補正}

環境温湿度の影響については， $\mathrm{K}-\mathrm{M}$ 值の変化量によ る補正はできなかった。そこで，絶対湿度による補正法 について検討した，絶対湿度 $H$ と試料水分 $W$ とは直線 関係にあると仮定すると，これらの関係は式（1）で表 すことができる。

$$
\begin{aligned}
& W=a(0)\{a(1)+H\} \\
& a(i): \text { 定数 }(i=0,1)
\end{aligned}
$$

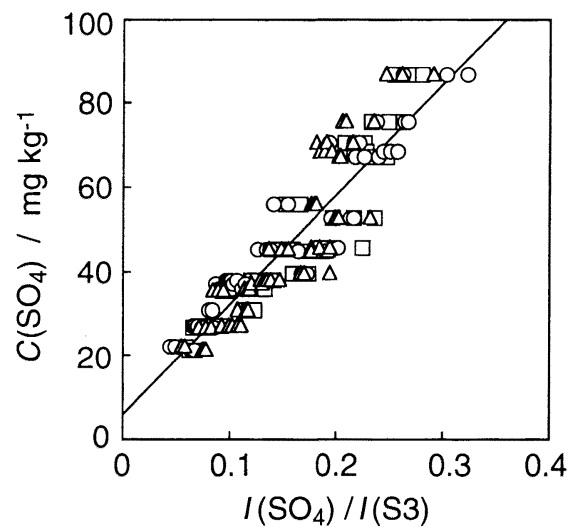

Fig. 9 Relation between the $I\left(\mathrm{SO}_{4}\right) / I(\mathrm{~S} 3)$ value and sulfate ion content by IC

$\bigcirc: 20^{\circ} \mathrm{C}, 40 \% ; \square: 40^{\circ} \mathrm{C}, 40 \% ; \triangle: 40^{\circ} \mathrm{C}, 70 \%$

又，光散乱度の補正に用いた $I(\mathrm{~S} 1)$ は試料水分に比例 すると仮定すると，試料水分の影響を考慮した光散乱度 の補正值 $I(\mathrm{~S} 2)$ は式 $(2$ ) で表すことができる.

$$
I(\mathrm{~S} 2)=I(\mathrm{~S} 1) / W
$$

式(1)，（2）より，式(3）が導出できる.

$$
I(\mathrm{~S} 2)=I(\mathrm{~S} 1) /[a(0)\{a(1)+H\}]
$$

$a(0)$ は定数であるので，補正值を $I(\mathrm{~S} 3)=a(0) I(\mathrm{~S} 2)$ に置き替えると，硫酸イオンのピーク強度の補正值は 式(4)となる.

$$
I\left(\mathrm{SO}_{4}\right) / I(\mathrm{~S} 3)=I\left(\mathrm{SO}_{4}\right)\{a(1)+H\} / I(\mathrm{~S} 1)
$$

ここで, $C\left(\mathrm{SO}_{4}\right)$ と $I\left(\mathrm{SO}_{4}\right)\{a(1)+H\} / I(\mathrm{~S} 1)$ との関係 より，適合性が最良になる定数 $a(1)$ を決定した。

Fig. 9 に決定した $a(1)$ を用いて, $C\left(\mathrm{SO}_{4}\right)$ と $I\left(\mathrm{SO}_{4}\right) /$ $I(\mathrm{~S} 3)$ との関係を示す. 分散の推定值は 49.31 であり, Fig. 6 に示した補正を行わなかった場合の 74.78 と比較 して，適合性は大幅に向上したことから，絶対湿度を用 いて試料水分を考慮した光散乱度補正は有効な方法であ った.

\section{$3 \cdot 7$ 工程管理への適用}

実工程の包装室には空調設備があり，絶対湿度は，環 境温湿度の影響について検討した範囲ほど大きく変化せ 


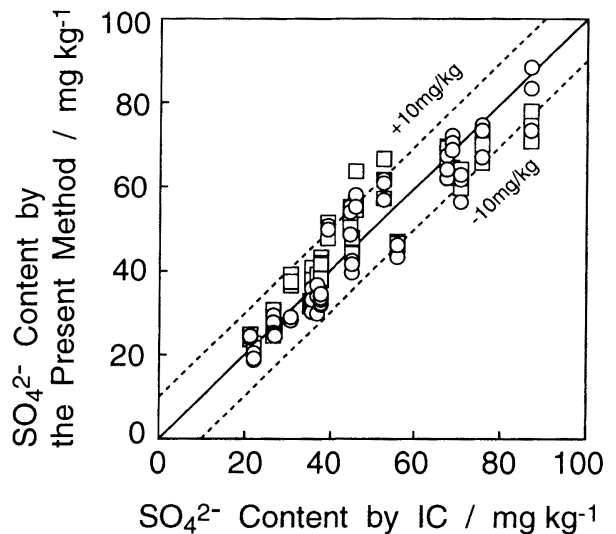

Fig. 10 Plots of sulfate ion content by the present method vs. by IC

: $20{ }^{\circ} \mathrm{C}, 40 \% ; \square: 40{ }^{\circ} \mathrm{C}, 40 \%$

ず，少なくとも $0.0058 \mathrm{~kg}\left(\mathrm{H}_{2} \mathrm{O}\right) \mathrm{kg}^{-1}$ (dry-air) $\left(20^{\circ} \mathrm{C}\right.$ $40 \%) \sim 0.0186 \mathrm{~kg}\left(\mathrm{H}_{2} \mathrm{O}\right) \mathrm{kg}^{-1}$ (dry-air) $\left(40^{\circ} \mathrm{C} 40 \%\right)$ の範 囲内にある.このため, この絶対湿度範囲で, 硫酸イオ ン含有量の簡易測定を行った場合，IC 法による分析値 と本簡易測定法による測定值とは, Fig. 10 に示す関係 となる. 分散の推定值は 42.18 であり, 測定值と分析值 はほぼ $10 \mathrm{mg} \mathrm{kg}^{-1}$ の範囲に入っており, 工程管理用の 簡易測定法として十分な測定精度であると考えられる。

\section{$3 \cdot 8$ 再現性}

環境温湿度 $20^{\circ} \mathrm{C} 40 \%$ の製品試料を用いて, 再現性に ついて検討した．同一の試料を詰め替えずに 10 回の繰 り返し測定を行った場合， $I\left(\mathrm{SO}_{4}\right)$ の RSD は $1.1 \%$ であ り, 光散乱度補正に用いた $I(\mathrm{~S} 1)$ の $\mathrm{RSD}$ は $1.4 \%$ と装
置の変動による測定䛊差はほとんどなかった，又，同一 の試料を詰め替えて 10 回の測定を行った場合, $I\left(\mathrm{SO}_{4}\right)$ の RSD は $13.8 \% ， I(\mathrm{~S} 1)$ の RSD は $16.6 \%$ と光散乱度の 影響により，再現性は悪かった。しかし，簡易測定に用 いる補正值 $I\left(\mathrm{SO}_{4}\right) / I(\mathrm{SI})$ の $\mathrm{RSD}$ は $4.6 \%$ であり, 簡易 測定としては十分な繰り返し精度であった。

以上の結果より，本簡易測定法は試料の赤外拡散反射 スペクトルと試料環境の絶対湿度を測定し, 測定したス ペクトルから算出した $I\left(\mathrm{SO}_{4}\right), I(\mathrm{~S} 1)$ と絶対湿度 $H$ か ら試料の硫酸イオン含有量を算出する方法であり, 試料 の充てん密度, 粒径, 粒径分布及び環境温湿度による影 響を補正できる，又，再現性も良好であり，溶解再製製 塩法で製造される高純度塩の硫酸イオン含有量の簡易測 定に十分対応できると考えられる.

$$
\left(\begin{array}{l}
1997 \text { 年 } 6 \text { 月, 日本海水 } \\
\text { 学会第 } 48 \text { 年会にて発表 }
\end{array}\right)
$$

\section{文献}

1) 村上正祥: 日本海水学会誌, 47, 375 (1993).

2) 日本海水学会, (財)ソルトサイエンス研究財団共 編: “塩の分析と物性測定”, p. 157 (1992), (日本 海水学会).

3) 金田英彦, 手塚真知子, 田中誠之: 分析化学 (Bunseki Kagaku), 41, 601 (1992).

4) 島田武彦: “赤外線吸収スペクトル解析法第 7 版”, p. 16 (1967), (南江堂).

5) 田隈三夫: “FT-IR の基礎と実際 第 2 版”, p. 100 (1994), (東京化学同人).

6) 島田武彦: “赤外線吸収スペクトル解析法 第 7 版”, p. 91 (1967), (南江堂).

7) 田隈三夫: “FT-IR の基礎と実際 第 2 版”, p. 97 (1994), (東京化学同人).

\section{要 旨}

溶解再製製塩法で製造される高純度塩の不純物は, 硫酸イオンが主体であるため, 製品の硫酸イオン 含有量の管理は重要である. 従来より, 製品の硫酸イオン含有量の管理は, イオンクロマトグラフ法に より行っているが, 試料の前処理が必要であり, 分析時間も長いため, 簡便, 迅速な簡易測定法の開発 が求められている，そこで，本報告では，赤外拡散反射法による硫酸イオン含有量の簡易測定法につい て検討した。その結果, 赤外拡散反射法により測定した硫酸イオン特有の SO 縮重伸縮振動のピーク強 度を, 試料の充てん状態, 粒径及び粒径分布による光散乱度の影響に起因する $1900 \sim 2090 \mathrm{~cm}^{-1}$ の Kubelka-Munk（K-M）值の変化量及び環境温湿度の影響を絶対湿度で補正することにより, 測定誤 差 $10 \mathrm{mg} \mathrm{kg}^{-1}$ 程度, 繰り返し精度 $4.6 \%$ で, 高純度塩の硫酸イオン含有量を非破壊で簡易測定できる 方法を開発した，本法は，簡易測定に十分な測定精度を持ち，測定時間も 1 分程度と短時間であるため, 製品管理，工程管理に十分対応できると考えられる. 